\title{
Climate Change Impact on Rainfall: How will Threaten Wheat Yield?
}

\author{
K.Tafoughalti ${ }^{1 *}$, E.M. El Faleh ${ }^{1}, Y$. Moujahid ${ }^{2}, F$. Ouargaga $^{1}$ \\ ${ }^{1}$ Geosciences, Patrimony useful Substances lab, Department of Geology, Faculty of Sciences, UMI - \\ Meknes, Morocco \\ ${ }^{2}$ Regional Center for Agricultural Research - URGDRNESR, Meknes, Morocco
}

\begin{abstract}
Climate change has a significant impact on the environmental condition of the agricultural region. Meknes has an agrarian economy and wheat production is of paramount importance. As most arable area are under rainfed system, Meknes is one of the sensitive regions to rainfall variability and consequently to climate change. Therefore, the use of changes in rainfall is vital for detecting the influence of climate system on agricultural productivity. This article identifies rainfall temporal variability and its impact on wheat yields. We used monthly rainfall records for three decades and wheat yields records of fifteen years. Rainfall variability is assessed utilizing the precipitation concentration index and the variation coefficient. The association between wheat yields and cumulative rainfall amounts of different scales was calculated based on a regression model.

The analysis shown moderate seasonal and irregular annual rainfall distribution. Yields fluctuated from 210 to $4500 \mathrm{Kg} / \mathrm{ha}$ with $52 \%$ of coefficient of variation. The correlation results shows that wheat yields are strongly correlated with rainfall of the period January to March. This investigation concluded that climate change is altering wheat yield and it is crucial to adept the necessary adaptation to challenge the risk.
\end{abstract}

Keywords: Climate change, wheat yield, rainfall variability, precipitation concentration index.

\section{Introduction}

Climate change is considered to be a world-wide phenomenon. The effect that it will have on agriculture is the biggest concerns. Morocco is especially notable for its vulnerability to climate change [1], climate is characterized by long periods of drought and a strong interannual variability in rainfall amount and distribution [2-4]. In the past few decades Moroccan agriculture have been suffering from severe water resources deficits [5-7].

\footnotetext{
* Corresponding author: khalid.tafoughalt@gmail.com ;
} 
Various studies has reported varied eff ect of climate variations on agricultural production [1, 8-10]. In Morocco, cereals represents the main crop and are of great importance to national food security; the main part of the diet comes directly or indirectly from cereals [11]. Compared to other countries in the Mediterranean Basin, Production levels are generally poor [12]; the most due to direct exposure to nature. The heaviest bills are those of cereals, which represent almost $36 \%$ of imports in 2014 [13].

In earlier studies, Jarlan [14] has mentioned that the development of cereals is related to local environmental conditions, among which water availability are the most decisive. This discovery is consistent with previous works [15-17] and indicate the need for local specific studies.

Rainfall furnish the water which contributes to the transportation of the nutrients for plants development. In consideration of this essential role, deficiency of water supply, especially during critical developmental stages has negative effects on efficient plants growth, resulting enormous yield reductions.

Meknes is among the provinces that contribute most to national wheat production. Considering that $97 \%$ of total cultivated area is non-irrigated, this makes the agricultural system in the region vulnerable to dry spells and uneven distribution of the rainfall. What might straightly influencing the livelihood of the inhabitants.

Our ongoing study analyses rainfall variability at annual, seasonal and monthly scales and evaluate the correlation between rainfall and the yields of wheat, then it could be used in developing risk reducing strategies.

\section{Material and methods}

\subsection{Study area}

The domain of study was Meknes province north-west of Morocco (Figure 1). It is situated between longitude $33^{\circ} 88 \mathrm{~N}$ and latitudes $5^{\circ} 53 \mathrm{~S}$. It has an area of $1692 \mathrm{~km} 2$. Characterized by a semi continental climate of Mediterranean type, with cool winters and rainy and hot summers and dry. The temperatures means range from $3{ }^{\circ} \mathrm{C}$ in cool season and $34{ }^{\circ} \mathrm{C}$ in hot season. The average annual rainfall ranges from 450 to $600 \mathrm{~mm}$.

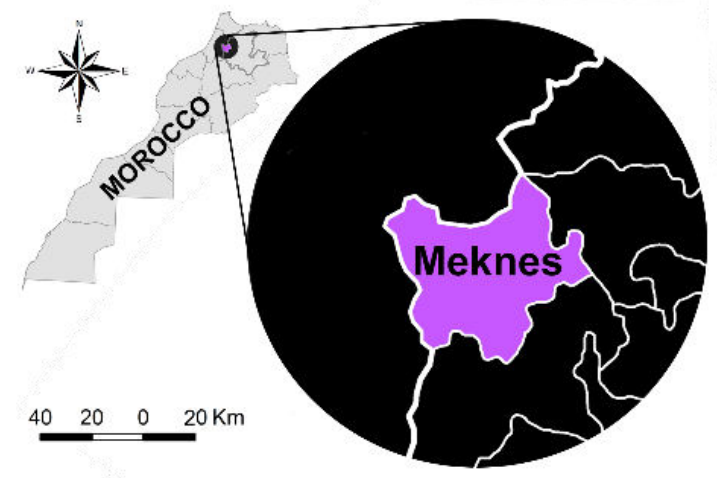

Fig.1. Location of Meknes in Morocco

\subsection{Data and analysis}

A rainfall data recorded over three decades (from 1985 to 2016) and crop yield records of soft wheat and hard wheat from 1995 to 2015 were provided by DPA; Provincial Department of Agriculture in Meknes. The mean and Coefficient of Variation (CV), Standard Deviation (SD) of monthly, seasonal and annual rainfall are computed by using 
Excel software. The Precipitation Concentration Index (PCI, [18, 19]), was calculated on an annual scale, seasonal scale for winter (DJF), spring (MAM), autumn (SON), and on supraseasonal scale for wet season (ONDJFM) by means of the following equation:

$$
P C I=[C V * P i]^{2}+1 / n
$$

Where $\mathrm{Pi}$ is the monthly precipitation in month $\mathrm{i}, \mathrm{CV}$ is variance.

Each month is represented by its first letter e.g. ONDJFMAM = October November December January February March April May.

According to Oliver's classification:

A PCI values of less than 10 represent a uniform precipitation distribution; PCI values from 11 to 15 denote a moderate precipitation concentration; values from 16 to 20 denote irregular distribution and values above 20 indicates a strong irregularity (i.e., high precipitation concentration).

To evaluate the relationship between rainfall and wheat yields we used the correlation analysis. The calculation of the correlation coefficient is performed using Equation (1), in which rainfall represents the independent variable $(\mathrm{X})$ and wheat yield represents the dependent variable (Y).

$$
r=\frac{\sum(x-\bar{x})(y-\bar{y})}{\sqrt{\sum(x-\bar{x})^{2}(y-\bar{y})^{2}}}
$$

Where $\ddot{x}$ and $\bar{y}$ are the mean of the matrix X and the matrix Y respectively.

\section{Result and discussion}

\subsection{Rainfall pattern}

The trend of the total annual rainfall (mm) from 1984-2015 in Meknes province is as shown in the Figure 2. The annual rainfall volume was variable from year to year and ranges from $284 \mathrm{~mm}$ to $876 \mathrm{~mm}$. In seasons 2008-2009, 2009-2010 and 2012-2013 the annual rainfall amounts surpass $800 \mathrm{~mm}$ and fall below $300 \mathrm{~mm}$ in 1994-1995.

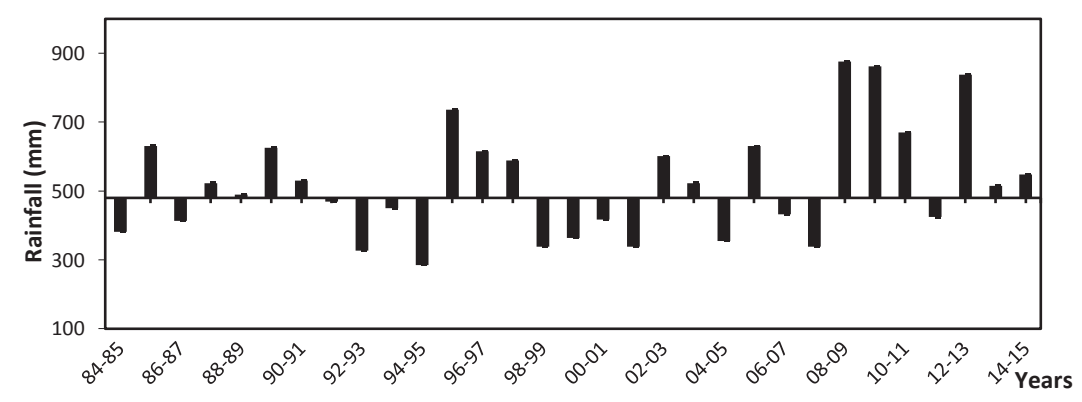

Fig.2. Annual rainfall compared with the median

From Table 1 one can learn that growing season account $93 \%$ of total annual rainfall where more than $46 \%$ occurs in winter-season and approximately $20 \%$ in the ending of autumn and $20 \%$ at the beginning of spring.

Table 1: Statistics for rainfall of multiple time scales from 1984 to 2016 


\begin{tabular}{lllllll}
\hline & Annual & Growing Season & Supra-Season & Autumn & Winter & Spring \\
\hline Mean & 520 & 486 & 405 & 145 & 221 & 142 \\
Coefficient of Variation & 31 & 30 & 38 & 50 & 51 & 42 \\
PCI (\%) & 17 & 15 & 12 & 13 & 11 & 13 \\
\hline Total \% & 100 & 93 & 76 & 28 & 41 & 28 \\
\hline
\end{tabular}

\subsection{Wheat yield trends}

Historical records of soft and hard wheat yield from 1995 to 2015 as represented in Figure 3 , show that, in general, the yield is low and variable in time. The coefficient of variation was very high, showed $52 \%$ for soft wheat and $53 \%$ for hard wheat. The highest observed yield was approximately $4500 \mathrm{~kg} / \mathrm{ha}$ for both hard and soft wheat, registered in season 2014-2015, while the lowest yields were $210 \mathrm{~kg} / \mathrm{ha}$ for hard wheat and $240 \mathrm{~kg} / \mathrm{ha}$ for soft wheat obtained in season 1999-2000, it was a very dry year. Such variation has often exposed poor farmers to migration to cities.

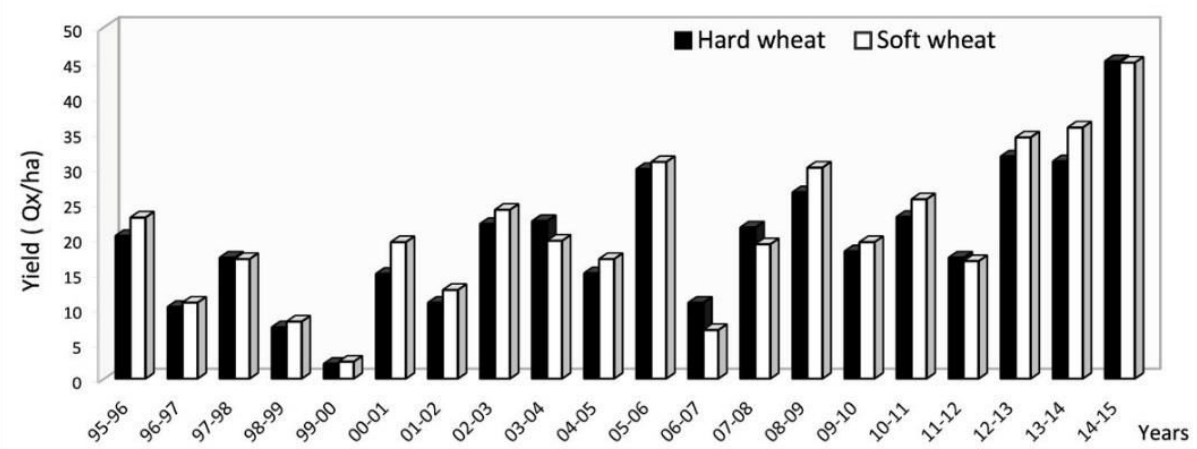

Fig.3. Variation of yield of hard wheat and soft wheat of Meknes from 1995 to 2015

\subsection{Variability of rainfall and distribution}

The rainfall variability resulted by coefficients of variation of seasonal and annual rainfall have shown that there existed a moderate variability, except for Autumn and Winter season where rainfall variability is high. Standard Deviation shows $72 \mathrm{~mm}$ for Autumn and $112 \mathrm{~mm}$ for winter, such values can lead to a success or failure of the crops. Additionally, on yearly basis, the computed PCI annual value of $17 \%$ indicates that, rainfall distribution over months is erratic. Generally dry years have recorded a high values (PCI ranges from 15 to 25). Nonetheless, the PCI value for season indicates moderate rainfall concentration $(\mathrm{PCI}<13)$.

Monthly average rainfall in Meknes is a clear seasonal cycle. Generally most of the precipitation occurs between November and January. This situation often fills the soil profile of the coarse-textured soil. A preview of the monthly rainfall trend over the period of two decades shows that monthly rainfall amount tend to decline in February after reaching its peak in December and January.

In respect to distribution, Figure 4 show that rainfall in the month of February and March are very erratic; the variation coefficient showed respectively $78 \%$ and $87 \%$. This 
might present dangers of water stress and dry spells which has a proven effect on yield since it coincide with production phase.
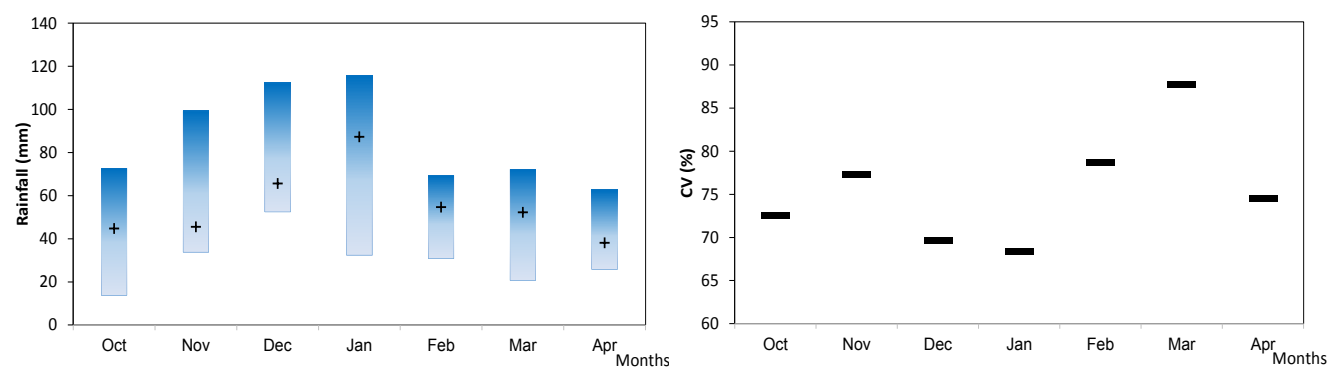

Fig.4. Box plot and coefficient of variation of monthly rainfall (Oct to Apr) from 1995 to 2016.

\subsection{Relationship between rainfall and wheat yield}

The Table 2 shows the relationship between rainfall of different period and wheat yield. Whereby all results, for seasons and inter-seasons are positive and significant.

For spring the correlation coefficient value was low. It showed 0.18; unfortunately, because the most rainfall of this season (March to May) coincides with wheat maturation. While a moderate amount of rainfall benefits wheat grain development, however, waterlogged soils during grain fill contribute to high disease pressure and can reduce wheat yields and test weight.

In contrast, a strong correlation were illustrated between wheat yield and rainfall at the other intervals; the correlation coefficients range from 0.52 to 0.76 . Thus revealing that the beginning and the middle of growth period is the most sensitive stages of growth to rainfall. Owing to the fact that the water supply from rainfall during this period will affect the root yield, the survival and fertilization of ears and consequently of the grains. The highest value of correlation was 0.73 obtained between wheat yield and rainfall of January to March (JFM).

These results reveal on the one hand the importance of rainfall volume of the period January to March, on the other hand the damaging effect of mid-spring rains. Both factors independently influencing annual yield of soft and hard wheat.

Table 2: Coefficients of determination showing the relationship between wheat yield and rainfall at different time scales.

\begin{tabular}{|c|c|c|c|c|c|c|c|c|c|c|}
\hline \multirow{2}{*}{ Crop/Time } & \multirow{2}{*}{ Annual } & \multirow{2}{*}{$\begin{array}{c}\text { Grow } \\
\text { season }\end{array}$} & \multirow{2}{*}{$\begin{array}{l}\text { Supra- } \\
\text { season }\end{array}$} & \multirow{2}{*}{$\begin{array}{l}\text { Autumn } \\
\text { (SON) }\end{array}$} & \multirow{2}{*}{$\begin{array}{c}\text { Winter } \\
\text { (DJF) }\end{array}$} & \multirow{2}{*}{$\begin{array}{l}\text { Spring } \\
\text { (MAM) }\end{array}$} & \multicolumn{4}{|c|}{ Inter-season } \\
\hline & & & & & & & ONDJ & JFMA & JFM & FMA \\
\hline Wheat & 0,66 & 0,72 & 0,76 & 0,57 & 0,52 & 0,18 & 0,62 & 0,64 & 0,73 & 0,53 \\
\hline
\end{tabular}

\section{Conclusion}

The study quantifies the impact of climate change on wheat production by assessing the rainfall variability and its relationship with wheat yields in Meknes province of Morocco. It revealed moderate seasonal and irregular annual rainfall concentration. When the estimated correlation between wheat yield and rainfall at different scale showed a significant effect of the precipitation. The yield variability showed a higher relationship with precipitation at 
small period (January to march). Seen the degree of rainfall variation of month in this period, wheat cropping would be more risky.

Having these results, without considering changes in practices of water-conservation, irrigation schemes, varieties and other, wheat yield might be in big trouble.

\section{References}

1. Barron, J., Rockström, J., Gichuki, F., \& Hatibu, N. (2003). Dry spell analysis and maize yields for two semi-arid locations in east Africa. Agricultural and forest meteorology, 117(1), pp 23-37.

2. Born, K., Fink, A. H., \& Paeth, H. (2008). Dry and wet periods in the northwestern Maghreb for present day and future climate conditions. Meteorologische Zeitschrift, 17(5), pp 533-551.

3. Chbouki, N., Stockton, C.W., Myers, D.E., 1995. Spatio-temporal patterns of drought in Morocco. Int. J. Climatol. 15 (2), pp 187-205.

4. FAO, 2006. The State of Food and Agriculture 2006: Food Aid for Food Security? FAO, Rome.

5. FAOStat, 2016. FAOSTAT database collections. Food and Agriculture Organization of the United Nations. http://faostat.fao.org.

6. Jarlan, L., Abaoui, J., Duchemin, B., Ouldbba, A., Tourre, Y. M., Khabba, S., ... \& Chehbouni, G. (2014). Linkages between common wheat yields and climate in Morocco (1982-2008). International journal of biometeorology, 58(7), pp14891502.

7. Jouve, P., \& Daoudi, A. (1984). Effets de la date de semis sur l'elaboration du rendement du blé tendre et de l'orge en zones semi-arides et arides (cas du Maroc atlantique). L'agronomie tropicale, 39(3), pp 216-228.

8. Lobell, D. B., \& Field, C. B. (2007). Global scale climate-crop yield relationships and the impacts of recent warming. Environmental research letters, 2(1), pp 014002.

9. Laux, P., Kunstmann, H., \& Bárdossy, A. (2008). Predicting the regional onset of the rainy season in West Africa. International Journal of Climatology, 28(3), pp 329-342.

10. MAPM, (ed.). 2015. L'agriculture marocaine en chiffres 2014, Statistique du ministère de l'agriculture et de la pêche maritimes, Rabat.

11. Karrou, M., \& Oweis, T. (2014). Assessment of the severity and impact of drought spells on rainfed cereals in Morocco. African Journal of Agricultural Research, 9(49), pp 3519-3530.

12. Oliver, J. E. (1980). Monthly precipitation distribution: a comparative index. The Professional Geographer, 32(3), pp 300-309.

13. Pala, M., Oweis, T., Benli, B., De Pauw, E., El Mourid, M., Karrou, M., ... \& Zencirci, N. (2011). Assessment of wheat yield gap in the Mediterranean: case studies from Morocco, Syria and Turkey. International Center for Agricultural Research in the Dry Areas (ICARDA), Aleppo, Syria. iv, pp 963-21.

14. Requier-Desjardins, M. (2010). Impacts des changements climatiques sur l'agriculture au Maroc et en Tunisie et priorités d'adaptation. Centre International de Hautes Études Agronomiques Méditerranéennes, Montpellier.

15. Sebbar, A., Badri, W., Fougrach, H., Hsaine, M., \& Saloui, A. (2011). Étude de la variabilité du régime pluviométrique au Maroc septentrional (1935-2004). Science et changements planétaires/Sécheresse, 22(3), pp 139-148. 
16. SEBBAR, A., HSAINE, M., FOUGRACH, H., \& BADRI, W. (2012). Étude des variations climatiques de la région centre du Maroc. Les climats régionaux: observation et modélisation, pp 709-714.

17. Sowers, J., Vengosh, A., \& Weinthal, E. (2011). Climate change, water resources, and the politics of adaptation in the Middle East and North Africa. Climatic Change, 104(3), pp 599-627.

18. Watts, D. G., \& El-Mourid, M. (1988). Rainfall patterns and probabilities in the semi-arid cereal production region of Morocco.

19. Zeggaf, T. A., Nsarellah, N., Hadrabach, D., \& Baidani, A. (2002). Caractérisation de la variabilitéspatiale du climat marocain en relation avec la productivité des céréales à petites graines. Rev. HTE, (124), pp 84-92.

20. Stocker, T. (ed.). (2014). Climate change 2013: the physical science basis: Working Group I contribution to the Fifth assessment report of the Intergovernmental Panel on Climate Change. Cambridge University Press. 